\title{
The Rhetoric of Persian News Headlines: A Case Study of Euronews
}

\author{
Roya Monsefi (Corresponding author) \\ School of Languages, Literacies and Translation, Universiti Sains Malaysia, Penang, Malaysia \\ E-mail: monsefi_roya@yahoo.com \\ Tengku Sepora Tengku Mahadi \\ School of Languages, Literacies and Translation, Universiti Sains Malaysia, Penang, Malaysia \\ E-mail: tsepora@usm.my
}

Received: 03-09-2016

Published: 01-03-2017
Accepted: 12-11-2016

doi:10.7575/aiac.ijalel.v.6n.2p.36
Advance Access Published: January 2017

URL: http://dx.doi.org/10.7575/aiac.ijalel.v.6n.2p.36

\begin{abstract}
Media texts are often filled with strategies to persuade the readers and express ideas beyond the plain meaning of the words. The present study investigated the rhetorical features of Persian news headlines through the analysis of wordplay. A sample of 100 online news headlines of Euronews was selected. Wordplay was analysed because of its role in persuasion. The method was descriptive and the data was analysed on the basis of textual rhetorical analysis. Leigh's (1994) framework including a taxonomy of different types of wordplay was adopted. Results revealed that the Persian news headlines of Euronews contained one or more clearly defined wordplay types. Tropes, or more specifically metonymies, were of the highest prevalence and wordplays such as oxymorons, parodies, anthimerias, polysyndetons, anadiploses, antimetaboles, epistrophes, climaxes and polyptotons were not present. The category of schemes encompassed the majority of unused wordplays. The discussion suggests that wordplay made the headlines more vivid and conspicuous.
\end{abstract}

Keywords: Wordplay, Persuasion, Online News Headlines, Rhetoric, Schemes, Tropes

\section{Introduction}

Advertising and commercial logic play a determining role in the highly competitive world of news media. To beat the competition from other news producers and attract more readers, one particular piece of news may be put through various revision processes before it reaches its final version (Bielsa \& Bassnett, 2009).

Revision by news editors may fundamentally mean paying delicate attention to the choice of words to reflect the media's stand and at the same time to affect their specific target readers. Though this focus on words applies to the whole piece of news, Russial (2004) and Rich (2010) mentioned that it seems to be more intense in news headlines; this feature of news is claimed to be an influential factor in tempting readers to read the whole piece of news. Fiske (1994) and Reinsch (1971) similarly suggested that the word choice of the writer can influence the readers' appreciation of the news. Because of the importance of headlines, Alexander (1997) observed that -headline writers tend to engage the headlines in different wordplay.

Wordplay, the action of determining the choice of words or combining words to create a certain effect, is generally a prominent means of persuasion that raises interest, builds attraction, and ultimately helps to sell products and ideas (Bonyadi \& Samuel, 2013; Henry \& Tator, 2002; Ifantidou, 2009; Leigh, 1994; McQuarrie \& Mick, 1993; Tuan, 2010). This significance of wordplay in headlines and its influence on present day readers represents the stimulus for the study that is embodied in the present paper. This study attempts to investigate wordplays in online Persian news headlines to determine if ideologies of journalists are explicitly served by the wordplay. In addition to the rationale explained above, the study also rests on the premise put forth by Van Dijk (2009) that a headline is the most prominent information of the news which comes first and summarises the story in the body.

News can be divided into three parts: the headline, the lead, and the body. The headline, as a text that appears at the top of a news article, usually provides the reader with an impression of what is to come and symbolises the most effective part of the article. Headlines have a characteristic style, different from the styles that prevail in ordinary sentences. Much information must be conveyed with few expressions; therefore, the way in which a message is exerted is a crucial consideration in headline construction. A well-developed headline can turn a browser into a reader (van Dijk, 1988). Criteria for briefness, vividness and attractiveness need to be applied at the lexical, syntactical as well as rhetorical levels (Khodabandeh, 2007a; Reah, 2002). This point is well reflected in The Media-Law Relations Committee (2005) reference to headlines as being a usual source of complaint from judges and lawyers primarily because headlines are 
written not by the reporters themselves but by copy editors or page editors who try to capture their perception of the news within the limitation of column space for the story.

In line with the idea that good headlines demonstrate precise communication with a handful of words, Rich (2010) described headlines as "microcontents", the smallest component of the story with the biggest influence on the reader. He judged a good headline as being a clear summary of the whole story; it normally contains strong verbs, prioritises important words first, is void of articles and may employ question forms if the issue is interesting enough to lure the readers. Rolnicki, Tate, and Taylor (2007) equated the newspaper readers with the tennis match watchers whose eyes dart from side to side, from photo to photo, from headline to headline to find a key word or phrase that makes them smile or touches them. They (2007) gave three reasons for headline importance: It condenses facts and ideas enabling the reader to decide with a simple glance on whether the news would present worthwhile reading. It allows the mood behind the story to come through, and also reveal the significance of the news in relation to the others.

Whatever the forms headlines take, language is the carrier of the message. As explained above, headline language is very different from common language in that it is a style of swift persuasion and immediate impact achieved through wordplay (i.e. using rhetorical figures). News Headlines have their own characteristics in employing rhetorical devices in order to engage attention and arouse curiosity. (Bonyadi \& Samuel, 2013; Ifantidou, 2009). While these have been said to be the characteristics of English news headline, it is not certain whether the same applies to headlines in other languages. The target language of interest in this study is Persian, a language from a distinctively different language family. Here, a case study is conducted to determine the type and prevalence of wordplay in Persian news headlines. In order to execute the study the following question stands out:

\section{- What types of wordplay are used in Persian news headlines of Euronews?}

\section{Literature Review}

More than 2000 years ago, rhetoricians like Aristotle unravel the concept and layers of what is known as rhetoric, and clarified its use as a means of persuasion. Today, when the subject of rhetoric is discussed, its legacy is often restricted to rhetorical figures of speech (van Dijk, 1988).

With the use of a variety of rhetorical devices, copy editors can change the ultimate meaning of the statement or the headline (Bizzell \& Herzberg, 2000). The first stage of any communication, which is called the "inventio" stage from the perspective of classical rhetoric, is the stage of selecting material to communicate. The producer of language always attempts to leave the impression in the receiver that s/he is trustworthy (Helder, 2011). The word choice in headlines, hence, is extremely important and headline writers clearly know this fact. Ptashchenko (2009), like many others, suggested that figures of speech (wordplay) such as puns, metaphors, similes, hyperboles, metonymies, and euphemisms help to persuade readers. While Ptashchenko (2009) named puns as a subclass of wordplay, other scholars employed the two notions of "wordplay" and "pun" interchangeably. (Koponen, 2004). McQuarrie and Mick (1992), in particular, generalised wordplay to resonance, metonymy, pun and metaphor, while Grinnell (1987) used the two terms of "rhetorical figures of speech" and "wordplay" interchangeably. The present study views "wordplay" and "rhetorical figures of speech" as being the same phenomena and thus uses them interchangeably.

There is a vast body of literature on studying the rhetoric of advertisement headlines in different languages (e.g. Cairns, 1998; Christopher, 2009; Jalilifar, 2010; Khodabandeh, 2007b; Kongpetch \& Smith, 2008; Leigh, 1994; McQuarrie \& Mick, 1992, 1993, 1996, 1999; Mooij, 2004; Patpong, 2008; Sacristán, 2006; Sidiropoulou, 1998; Smith, 2006; Tom \& Eves, 1999; Tuan, 2010; van Mulken, 2003). Tuan (2010) claimed that a rhetorical figure has the function of altering the way an advertisement is received and, as such, understanding the function and structure of rhetorical devices in advertisements needs a text and reader- aware approach; unfortunately this is sometimes ignored in present consumer research. The empirical study by Tom and Eves (1999) suggested that rhetorical figures of speech are efficient means of persuasion in advertisement headlines and proved that headlines which employ the rhetorical figures stimulated better recall and persuasion. News headlines, like advertisements, are fundamentally persuasive texts and accordingly wordplay is expected to play a similar role in the former. The analysis of Persian news headlines (as explained in the section below) will reveal this unique use of wordplay in Euronews headlines.

\section{Method}

The approach adopted for the study was qualitative. However, a simple frequency analysis was done in order to quantify the qualitative analysis. Chiluwa (2007) mentioned the independency of headlines as discourse units that can be analysed on their own. Accordingly, in order to determine the micro-rhetorical choices and play on words in headlines, rhetorical analysis within the context of textual analysis was applied.

The number of figures of speech appears to be quite imposing. As McGuigan (2008) argued, there are literally hundreds of figures of rhetoric that range from zeugma to anadiplosis. Some are barely used, while there are other figures of speech such as metaphor and hyperbole that are frequently used in speech and newspapers. The ancient Greeks and Romans introduced about two hundred and fifty different figures of speech; however, fewer than twenty percent of them are identified today. Corbett (1990) mentioned that the long list of figures of speech is actually a different form of about 40 general types. Accordingly, the broad category of figures of speech is generally divided to 40 or so key branches.

Scholars of classical western rhetoric have classified the figures of speech into two main categories of schemes and tropes. Some experts like Abrams and Harpham (2012), and Leech (1969) have divided the figurative language into two 
main classes of (1) figures of thought or tropes, and (2) figures of speech or rhetorical figures or schemes. As Abrams and Harpham (2012), and Leech (1969) argued, the separating border is not clean and significant, and disagreements exist between the experts in the field. Some theorists like Perrine (1963) employed the term figures of speech to refer to both tropes and schemes. Similarly, in the present study, based on Leigh's (1994) categorisation, wordplay (figures of speech) includes both "schemes" and "tropes".

\subsection{Theoretical Framework based on Leigh (1994)}

Leigh (1994) introduced 41 rhetorical figures that were divided into schemes and tropes. Schemes are figures of speech that deal with syntax, word order, letters and sounds rather than the meaning of words which includes tropes. In fact, schemes are deviation from the ordinary pattern or arrangement of words. On the other hand, tropes are figures which change the typical meaning of a word or words. They manifest deviation from the ordinary and basic meaning.

The "tropes" are divided into puns and associations. Pun can be claimed to be the most outstanding figure for using the play on words. It is usually a humorous use of a word or phrase that has more than one meaning. Pun is often used for emphasising or suggesting the different applications and meanings of a word. It is also the use of words that are similar or nearly similar in sound but different in meaning. In short, pun is a play sometimes on different senses of the same word and sometimes on a similar sense or sound of different words. Often puns demand a large body of vocabulary to be understood. Pun is called /jenâs/ in Persian. Associations, the second sub-category of tropes, are subdivided into six larger categories and their related 16 smaller subcategories.

The second sub-category of wordplay is the "schemes" which consist of word order --coordinated, deliberate word omissions and insertions, repetitions and rhyme. These four categories are also sub-divided into their related subcategories. The overall number of the subcategories is 20 . They are encapsulated in the lower section of figure 1 , below.

Figure 1 embodies Leigh's (1994) categorisation of wordplay. This model was also applied in Monsefi and Tengku Mahadi's (2016) study.

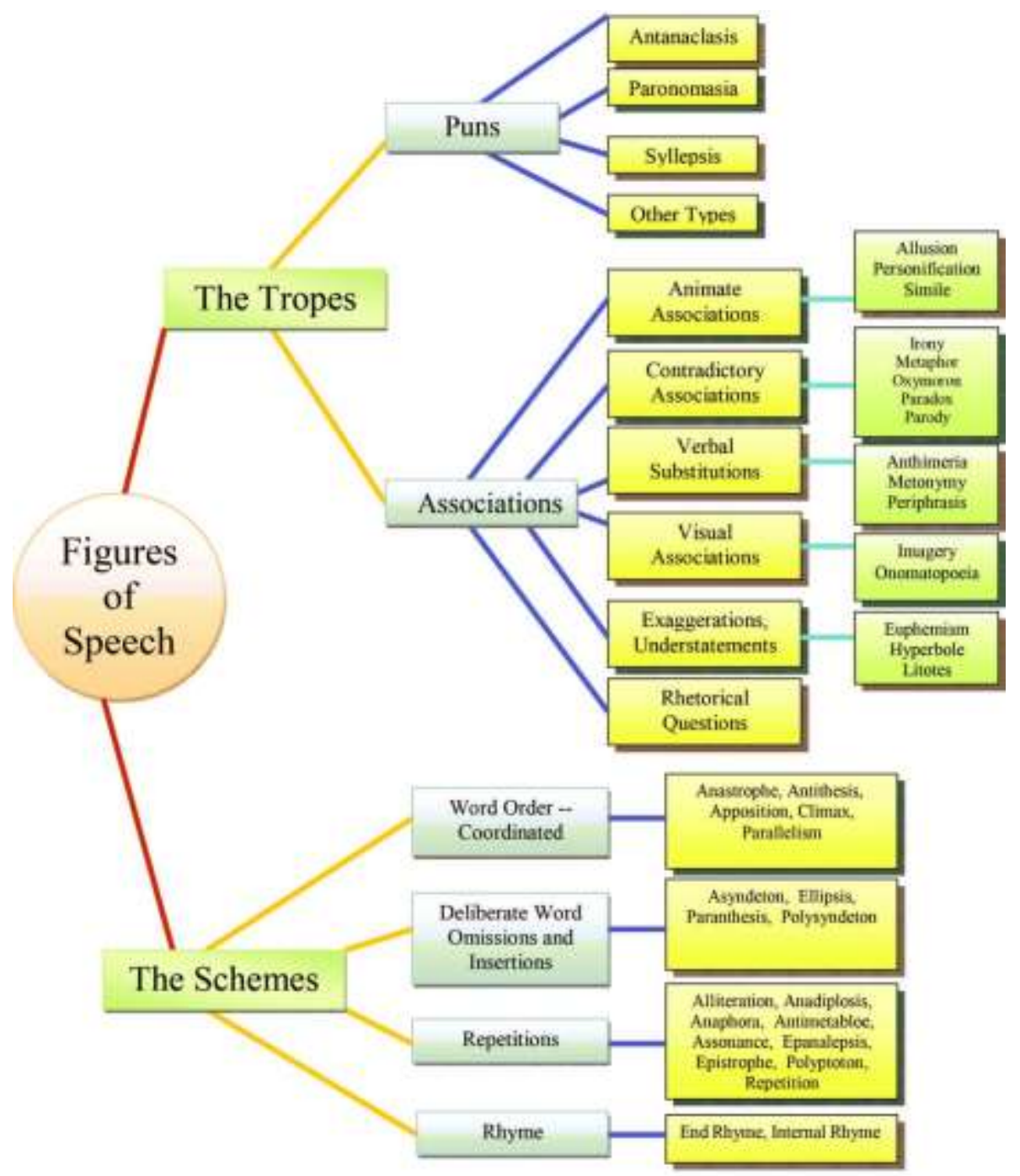

Figure 1. Taxonomy of Figures of Speech (Wordplay) by Leigh (1994)

While Leigh (1994) applied his taxonomy to investigate the wordplay in the advertising headlines, the present study applies it to the news headlines. 


\subsection{Corpus}

All the headlines subjected to analysis come from Euronews website. There are several reasons for this choice; First, Euronews has the international domain and covers news from all over the world: Africa, America, Asia, Europe, and Middle East. It is available in 155 countries across all platforms (websites, mobile apps, connected TVs, radio and YouTube). Second, it is claimed in Euronews website that it is the European leader in terms of audience figures in spite of the increasing competition. Third, it is the first multilingual news channel simultaneously available in 13 languages. The news texts are parallel in context and make any comparable study possible. In this study, the first 100 Persian news headlines of Farajian's (2011) English-Persian news corpus which is based on Euronews are investigated. The advantage of using this corpus is that the researcher's bias in selecting the headlines does not come into pictures. The selected news reports are originally in Persian but they are parallel in date and context with other 12 languages' news articles. The whole Persian news report was considered in the analysis in order to provide the context in which they were emerged.

\subsection{Procedure of the Study}

Applying the descriptive method, the procedure for data analysis is listed below.

1. Breaking down each Persian headline into its lexical components and providing English literal equivalent for each unit in order to make it possible for the non-Persian reader to decipher the units, then presenting a back translation of each Persian headline.

2. Conducting a textual rhetorical analysis of the news headline, adopting Leigh's (1994) framework, encapsulated in figure 1 , in order to detect wordplays and determine their types.

3. Applying the simple manual frequency analysis in order to provide a taxonomy of the frequency and percentage of each wordplay in news headlines, i.e. quantifying the qualitative analysis. The percentage will be calculated in the following way:

$$
\text { Percentage }=\frac{\text { Number of Occurrence }}{\text { Total Number }} \times 100
$$

\section{Result and Discussion}

Seventy-four percent of the selected "Persian" headlines of Euronews contained one or more clearly defined wordplay. However, according to Monsefi and Tengku Mahadi's (2016) study, the corresponding news headlines with wordplay in "English" were ninety-seven percent. These results suggested that English language news headlines were more likely to contain wordplay than news headlines that had been written in Persian. In Both English and Persian headlines metonymy was of the highest frequency and oxymoron, parody, anthimeria, rhetorical questions, antithesis, climax, parenthesis, polysyndeton, anadiplosis, antimetabole, assonance, epanalepsis, epistrophe, polyptoton, repetition and end rhyme were not present.

In order to better encapsulate the distribution of wordplays in 100 Persian news headlines, the following table (Table 1) and column chart (Figure 2) are presented. The percentage is found by taking the number of occurrences of an event (one wordplay), dividing by the total instances of wordplays examined, and multiplying by one hundred percent:

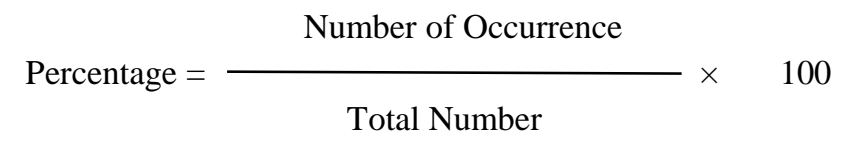

Example: $\quad$ Number of occurrence of Pun

Percentage of pun in 100 Persian News Headlines $=-\times 100=1.13 \%$ 
IJALEL 6(2):36-45, 2017

Table 1. The sum of the frequencies of wordplays in 100 Persian news headlines

\begin{tabular}{|c|c|c|}
\hline Wordplay Category & Frequency & Percentage \\
\hline Pun & 2 & $1.13 \%$ \\
\hline Allusion & 8 & $4.52 \%$ \\
\hline Personification & 29 & $16.38 \%$ \\
\hline Simile & 1 & $0.56 \%$ \\
\hline Irony & 1 & $0.56 \%$ \\
\hline Metaphor & 10 & $5.65 \%$ \\
\hline Oxymoron & 0 & $0 \%$ \\
\hline Paradox & 1 & $0.56 \%$ \\
\hline Parody & 0 & $0 \%$ \\
\hline Anthimeria & 0 & $0 \%$ \\
\hline Metonymy & 74 & $41.81 \%$ \\
\hline Periphrasis & 1 & $0.56 \%$ \\
\hline Imagery & 1 & $0.56 \%$ \\
\hline Onomatopoeia & 0 & $0 \%$ \\
\hline Euphemism & 3 & $1.69 \%$ \\
\hline Hyperbole & 12 & $6.78 \%$ \\
\hline Litotes & 0 & $0 \%$ \\
\hline Rhetorical Questions & 0 & $0 \%$ \\
\hline Anastrophe & 1 & $0.56 \%$ \\
\hline Antithesis & 0 & $0 \%$ \\
\hline Apposition & 4 & $2.26 \%$ \\
\hline Climax & 0 & $0 \%$ \\
\hline Parallelism & 1 & $0.56 \%$ \\
\hline Asyndeton & 0 & $0 \%$ \\
\hline Ellipsis & 22 & $12.43 \%$ \\
\hline Parenthesis & 0 & $0 \%$ \\
\hline Polysyndeton & 0 & $0 \%$ \\
\hline Alliteration & 4 & $2.26 \%$ \\
\hline Anadiplosis & 0 & $0 \%$ \\
\hline Anaphora & 1 & $0.56 \%$ \\
\hline Antimetabole & 0 & $0 \%$ \\
\hline Assonance & 0 & $0 \%$ \\
\hline Epanalepsis & 0 & $0 \%$ \\
\hline Epistrophe & 0 & $0 \%$ \\
\hline Polyptoton & 0 & $0 \%$ \\
\hline Repetition & 0 & $0 \%$ \\
\hline End Rhyme & 0 & $0 \%$ \\
\hline Internal Rhyme & 1 & $0.56 \%$ \\
\hline Sum & 177 & $100 \%$ \\
\hline
\end{tabular}

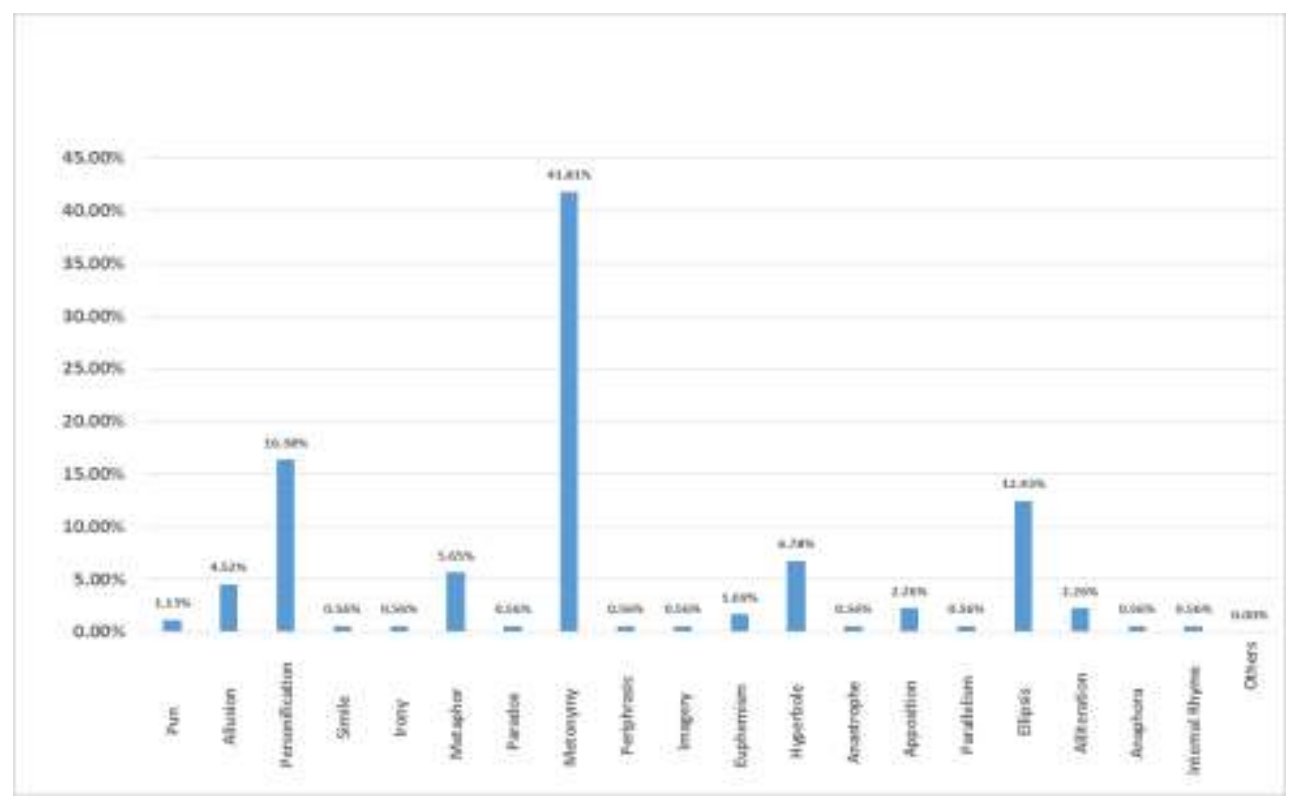

Figure 2. The Distributions of Wordplays in 100 Persian News Headlines 
According to Table 1 and Figure 2, the occurrence of Metonymy is noticeably greater than other wordplays in 100 Persian news headlines. In fact, the results suggested that forming the metonymic references in sending their message across was the first priority of headline writers in their wordplay selection. Personification was ranked second in number. In the majority of headlines, the presence of metonymy led to the occurrence of personification. For instance, in the news headline China closes Tibet to foreign visitors, China is used metonymically to refer to government officials of China. The use of metonymy evaded and blurred the role of responsible agents and united the nation with government officials in their decision making which also led to the trope Personification; i.e. as an inanimate entity China was incapable of "closing" any places.

Four samples of headlines are selected for discussion.

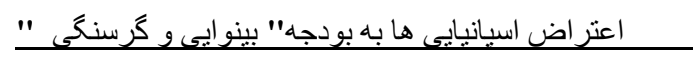

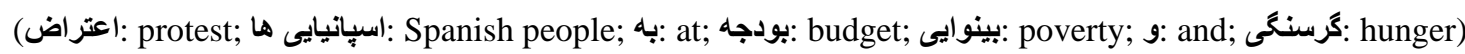

Back Translation: Protest of Spanish people at budget of "poverty and hunger"

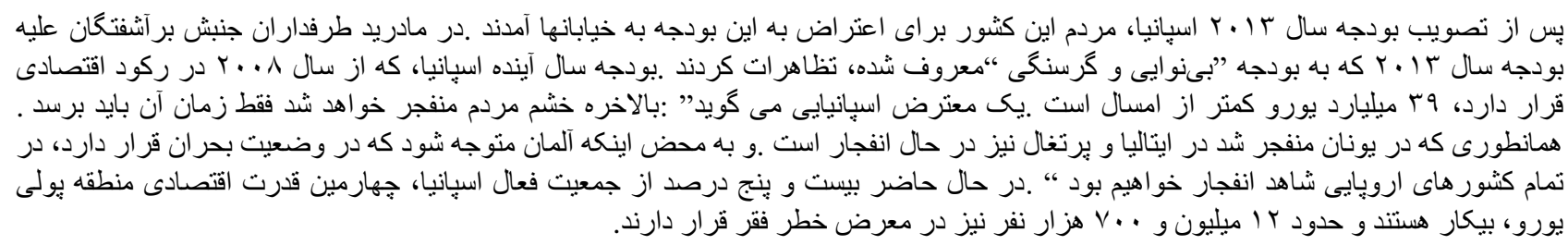

As Spanish government officials tried desperately to meet the country's budget targets, they had been forced to introduce one austerity measure after another, cut jobs, salaries, pensions and benefits, even as the economy continued to shrink. Spanish lawmakers claimed that the tough cuts were needed to fix the public finances. In response to the painful cuts in budget, Spanish protesters rallied in anger through the streets of Madrid to show their budget discontent.

In order to highlight the tough austerity measures, with the use of hyperbole, the Persian headline exaggerated the cuts in the budget in the phrase "بودجه بى نو ايى و كرسنحى" (budget of poverty and hunger). In addition, the phrase "hunger budget" created an irony. A "budget" is a description of a financial plan, i.e. it includes an estimate of costs, revenues, and resources over a specified period. With this concept in mind, having budget for hunger is an ironic wordplay; the budget should be determined to overcome hunger not to trigger it.

The wordplays can be summarised in the following table:

Table 2. The wordplay employed on the $1^{\text {st }}$ Persian headline

Wordplay

Schemes

Tropes

Hyperbole بودجه بينو ايى و كرسنگى (budget for poverty and hunger) Irony بودجه بينو ايیى و كرسنكى (budget for poverty and hunger)

The following example is the second headline selected for discussion:

(ليون: Lyon; فرنس: France; : غرق شدdrowned; در: in; نور: light) drowned in light

ليون فرانسه غرق در نور شد

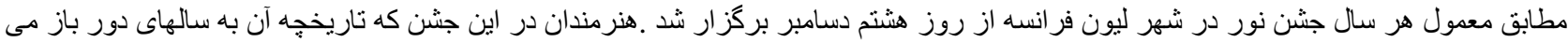

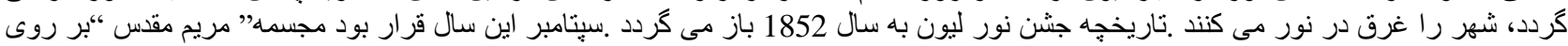

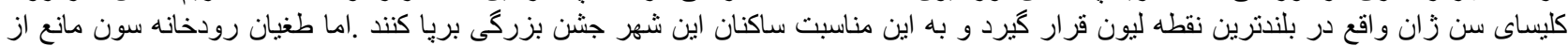

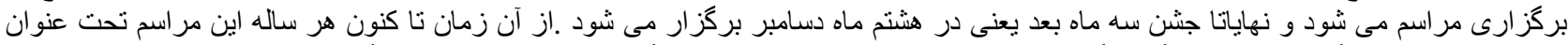

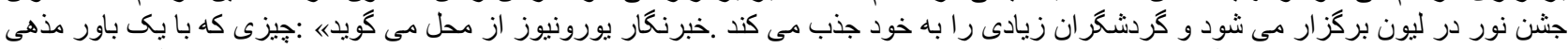

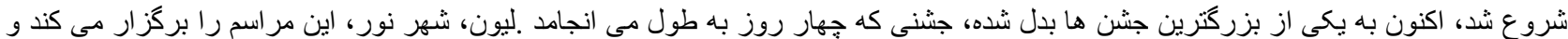

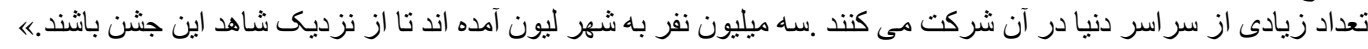

Dozens of spectacular light shows illuminate the skies over Lyon each year for the annual Festival of Lights. This festival draws millions to Lyon who come to gaze at flashes of light and flares, as well as performers and creative displays at this four-day event. The headline, using a hyperbole, depicted the message in an exaggerated way to cast emphasis on city lights, i.e. through personifying Lyon, the city was resembled to a person who was drowned in a sea of light $\rightarrow$ ليون فر انسه غرق در نور شد (Lyon of France drowned in light). This image also created a metaphor in which Light bore a resemblance to a sea that Lyon was getting drowned in it. The headline also contained one instance of Ellipsis which can be recovered in the following way: 
The wordplays utilised in the headline can be summarised in the following table:

Table 3 . The wordplay employed on the $2^{\text {nd }}$ Persian headline

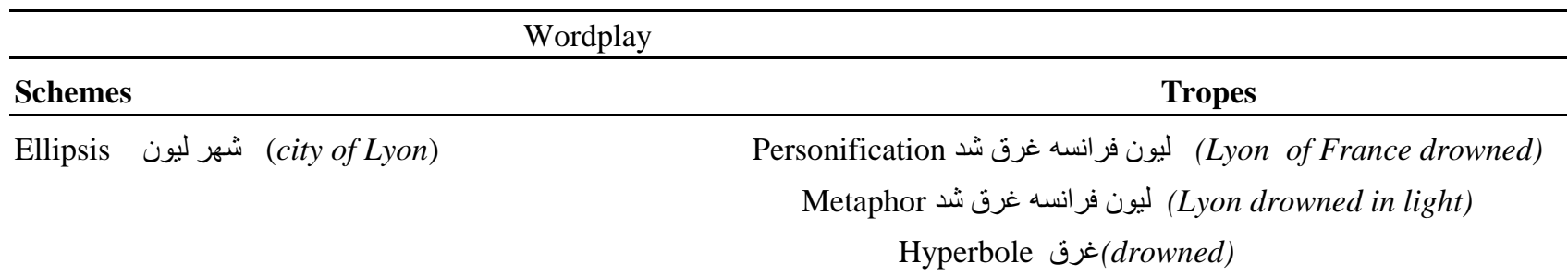

The third headline selected for review deals with the America's position towards the crisis in Europe.

آمريكا بحران مالحى منطقه يورو را جكونه مى بيند؟

(آمريكا: America; بحران: crisis; منطقه: financial; zone; يورو: Euro; الى: the;

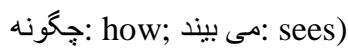

Back Translation: How does America see eurozone financial crisis?

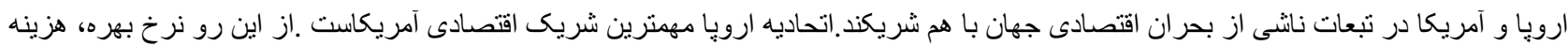

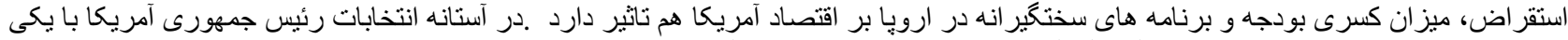

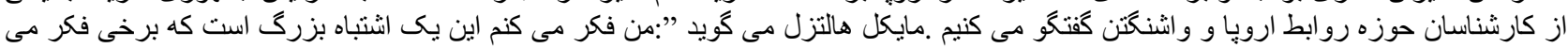

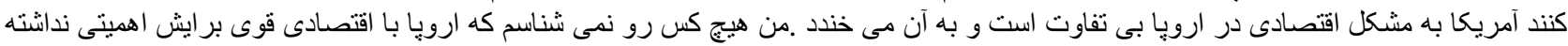

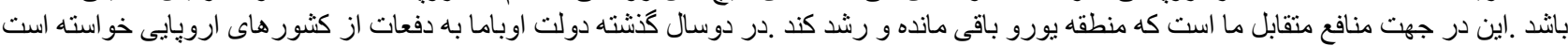

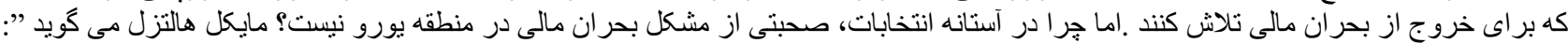

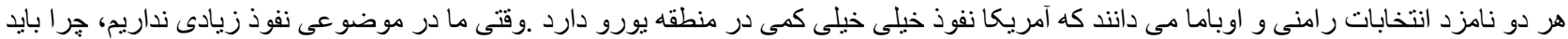

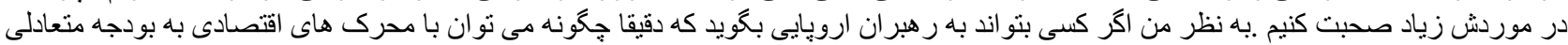

رسيد، مى تو اند كانديداى دريافت جايزه نوبل اقتصاد باثد."

There is one instance of metonymy in which (آمريكا: America) refers to US administrators. Concurrently, the implication of metonymy leads to the trope personification because the human trait of "seeing" is attributed to the inanimate entity, i.e. (آمريكا مى بيند: America sees). The occurrence of metonymy saves the space in the headline, evades the responsible agents, and unites the government with the nation in its policy making.

The following table better projects the wordplays:

Table 4. The wordplay employed on the $3^{\text {rd }}$ Persian headline

\begin{tabular}{|c|c|}
\hline \multicolumn{2}{|c|}{ Wordplay } \\
\hline Schemes & Tropes \\
\hline
\end{tabular}

The final example deals with the interception of Syrian passenger aircraft, suspected of carrying weapons, by Turkey's officials;

تركيه هواييماى مسافربرى سوريـه را مجبور به فرود كرد

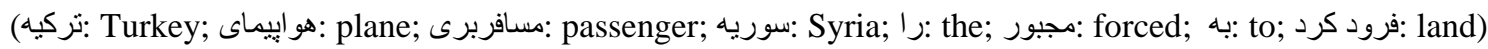

Back Translation: Turkey forced Syria passenger plane to land

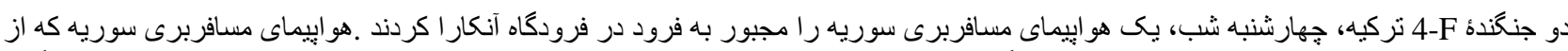

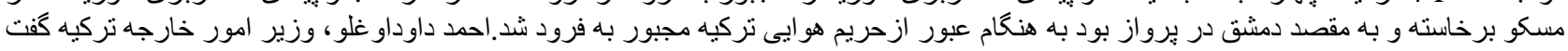

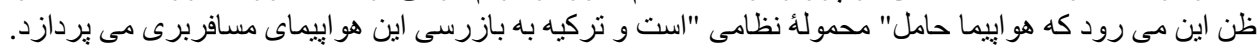

The country name Turkey topicalises the Persian headline and functions as an active actor. With the metonymic use of the country's name, the headline does not identify the individuals or groups responsible for landing the plane while "Turkey" has a metonymic reference of "Turkey's officials". The metonymy also leads to the trope, personification. As an inanimate entity, Turkey is incapable of "forcing a plane to land".

There are also two more instances of metonymy in the above headline. In Syria passenger plane, Syria has a metonymic reference of "Syria's air fleet", i.e. the headline writer uses the general term Syria to refer to Syria's air fleet as a specific property of Syria. Metonymy whole for part is used. Plane as an object is also used as a metonymy to refer to the "user" of that object, i.e. pilot $\rightarrow$ Turkey forces Syria passenger plane to land $\rightarrow$ Turkey forces Syria passenger pilot to land.

The summary of wordplay is presented in the following table: 


\begin{tabular}{ll}
\hline & Wordplay \\
\hline Schemes & Tropes \\
\hline
\end{tabular}

Metonymy (3) تركيه (Turkey), سوريه (Syria), هوريه (plane)

Personification تركبه مجبو كرد $\rightarrow$ تركية (Turkey forced)

The finding of the present study is in line with Smith's (2006) study of English-language printed advertisements who concluded that the wordplays used in his selected advertising headlines were more of trope category than the schemes. Meanwhile, in a contrastive study conducted by Bonyadi and Samuel (2013), the rhetorical devices in the 20 editorial headlines of English newspaper, The New York Times and those of Persian newspaper, Tehran Times were studied. The most frequent wordplay that emerged in their study in both English and Persian news headlines was also "metonymy" which can lead to the conclusion that copy editors favored using this wordplay the most.

It can be suggested that certain wordplays are more suited to headline copy.

\section{Conclusion}

In this study, wordplay is selected for examination because it is the effective means of persuasion that can influence the readers' attitude, experience and world perception. Wordplay is investigated in news headlines due to the headlines' prominent position in news articles and their determining function of persuasion. Headlines express the news with intention and express the news for attention.

The findings suggested that wordplays were frequently employed in Euronews Persian headlines. However, some were more prevalent than others in a particular frequency. It should be mentioned that the effects that wordplays had in shaping or changing the potential readers' thinking was not within the scope of the present study. This issue, as van Dijk $(1986,1988)$ mentioned, demands the psychological and sociological studies of news and fall under the category of sociocognitive approach to news analysis. On the other hand, the use of one news website can put limitations in making inferences. The wordplays used in the present corpus may not necessarily exist in all news websites and with different corpus different results can be obtainable. However, the present study can be a representative of wordplay manifestation in one news website.

Thus, the present research can exemplify how rhetoric may be utilised in practical ways in real life areas. It shows the ways copy editors persuade the readers through their language and express ideas beyond the plain meaning of the words. Examining wordplay uncovers principles and rules that are used for delivering language in a way that is impressive and persuasive. It is expected that this study be of worth for instructors who teach journalism or other related fields to give clarification of rhetorical devices in news headlines. It can also be helpful for students who study journalism, discourse and pragmatics to make use of the analysis of findings. Although these techniques were found with respect to Persian headlines, they can still be applied to other languages.

\section{References}

Abrams, M. H., \& Harpham, G. G. (2012). A glossary of literary terms. (10 ${ }^{\text {th }}$ ed.). Boston, MA: Wadsworth.

Alexander, R. J. (1997). Aspects of verbal humour in English. Tübingen: Gunter Narr Verlag.

Aristotle (2008). The art of rhetoric (W. R. Roberts, Trans.). Megaphone eBooks. (Original work published 300 B. C. E). Retrieved from http://www.wendelberger.com/downloads/Aristotle_Rhetoric.pdf (accessed 8 August 2016).

Bielsa, E., \& Bassnett, S. (2009). Translation in global news. London and New York: Routledge.

Bizzell, P., \& Herzberg, B. (2000). The rhetorical tradition: Readings from classical times to the present. Boston: Bedford.

Bonyadi, A., \& Samuel, M. (2013). Headlines in newspaper editorials: A contrastive study. Sage Open, 3(2), 1-10. doi: $10.1177 / 2158244013494863$

Cairns, J. (1998). Sociocultural persuasion in advertising: Considerations for translators. (Master dissertation). Retrieved from http://www.ruor.uottawa.ca/en/bitstream/handle/10393/4170/MQ36671.PDF?sequence=1 (accessed 20 November 2010).

Chiluwa, I. (2007). News headlines as pragmatic strategy in Nigerian press discourse. The International Journal of Language Society and Culture, (27), 63-71.

Christopher, A. A. (2009). A longitudinal study of the use of rhetorical figures and communicative and stylistic strategies in advertising slogans. (Doctoral dissertation). Retrieved from http://etheses.nottingham.ac.uk/1369/1/508196.pdf (accessed 8 August 2016).

Corbett, E. P. J. (1990). Classical rhetoric for the modern student. New York: Oxford University Press.

Farajian, M. A. (2011). PEN: Parallel English-Persian news corpus. In Proceedings of 2011 International Conference on Artificial Intelligence (ICAI'11). Nevada: USA. 
Fiske, J. (1994). Media matters: Everyday culture and political change. Minneapolis: University of Minnesota Press.

Grinnell, J. D. (1987). The National Register of Advertising Headlines \& Slogans. Westbury, NY: Asher-Gallant press.

Helder, B. (2011). Textual analysis: An approach to analysing professional texts. Frederiksberg: Samfundslitteratur.

Henry, F., \& Tator, C. (2002). Discourses of domination: Racial bias in the Canadian English-language press. Toronto: University of Toronto Press.

Ifantidou, E. (2009). Newspaper headlines and relevance: Ad hoc concepts in ad hoc contexts. Journal of Pragmatics, 41(4), 699-720.

Jalilifar, A. (2010). The rhetoric of Persian and English advertisements. The International Journal of Language Society and Culture, (30), 25-39.

Khodabandeh, F. (2007a). A contrastive analysis of English and Persian newspaper headlines. The Linguistics Journal, 2(1), 91-127.

Khodabandeh, F. (2007b). A contrastive analysis of rhetorical figures in English and Persian advertisements. The Asian ESP Journal, 3(2), 41-64.

Kongpetch, S., \& Smith, K. (2008). The language of the printed advertisement. Journal of Humanities and Social Science, 4(2), 149-178.

Koponen, M. (2004). Wordplay in Donald Duck comics and their Finnish translations. (Master dissertation). Retrieved from http://ethesis.helsinki.fi/julkaisut/hum/engla/pg/koponen/wordplay.pdf (accessed 8 August 2016).

Leech, G. N. (1969). A linguistic guide to English poetry. London: Longman.

Leigh, J. H. (1994). The use of figures of speech in print ad headlines. Journal of Advertising, 23(2), 17-33.

McGuigan, B. (2008). Rhetorical devices: A handbook and activities for student writers. Clayton, DE: Prestwick House.

McQuarrie, E. F., \& Mick, D. G. (1992). On resonance: A critical pluralistic inquiry into advertising rhetoric. The Journal of Consumer Research, 19(2), 180-197.

McQuarrie, E. F., \& Mick, D. G. (1993). Reflections on classical rhetoric and the incidence of figures of speech in contemporary magazine advertisements. Advances in consumer research, 20(1), 309-313.

McQuarrie, E. F., \& Mick, D. G. (1996). Figures of rhetoric in advertising language. The Journal of Consumer Research, 22(4), 424-438.

McQuarrie, E. F., \& Mick, D. G. (1999). Visual rhetoric in advertising: Text-Interpretive, experimental, and readerresponse analysis. The Journal of Consumer Research, 26(1), 37-54.

Monsefi, R., \& Tengku Mahadi, T. S. (2016). Wordplay in English online news headlines. Advances in Language and Literary Studies, 7(2), 68-75.

Mooij, M. D. (2004). Translating advertising: Painting the tip of an iceberg. The Translator, 10 (2), 179-198.

Patpong, P. J. (2008). Language of persuasion: An analysis of selected samples from talisman advertisements. Systemic Functional Linguistics in Use, OWPLC, 29, 633-664.

Perrine, L. (1963). Sound and sense: An introduction to poetry. New York: Harcourt Brace and World.

Ptashchenko, N. (2009). Headline as a persuasive tool in publicistic discourse: A case study on headlines from the English-language periodicals during the presidential election campaign in France-2007. Norderstedt: Grin Verlag.

Reah, D. (2002). The language of newspapers. New York: Routledge.

Reinsch, N. L. (1971). An investigation of the effects of the metaphor and simile in persuasive discourse. Speech Monographs, 38(2), 142-146.

Rich, C. (2010). Writing and reporting news: A coaching method. Boston: Wadsworth.

Rolnicki, T. E., Tate, C. D., \& Taylor, S. (2007). Scholastic journalism. Oxford: Blackwell publishing.

Russial, J. (2004). Strategic copy editing. New York: The Guilford Press.

Sacristán, M. V. (2006). Advertising English and ESP: The British Cosmopolitan ad as an example of "specialised text". Ibérica, (12), 65-88.

Sidiropoulou, M. (1998). Advertising in Translation: English vs. Greek. Meta: Translators' Journal, 43(2), 191-204.

Smith, K. (2006). Rhetorical figures and the translation of advertising headlines. Language and Literature, 15(2), 159182.

The Media-Law Relations Committee (2005). Wisconsin lawyers' guide to the news ( $3^{\text {rd }}$ ed.). State Bar of Wisconsin: Media-Law Relations Committee. Retrieved http://www.wisbar.org/AM/Template.cfm?Section=Media_Center\&Template=/CM/ContentDisplay.cfm\&ContentID=4 9273 (accessed 10 November 2010).

Tom, G., \& Eves, A. (1999). The use of rhetorical devices in advertising. Journal of Advertising Research, 39(4), 3943. 
Tuan, L. T. (2010). Rhetorical structures in the language of Vietnamese advertisements. Asian Social Science, 6(11), 175-182.

van Dijk, T. A. (1986). News schemata. New York: Dans Cooper and Greenbaum.

van Dijk, T. A. (1988). News as discourse. Hillsdale, New Jersey: Lawrence Erlbaum Associates, Publishers.

van Dijk, T. A. (2009). News, discourse, and ideology. In K. Wahl-Jorgensen, \& T. Hanitzsch (Eds.), The handbook of journalism studies (pp. 191-204). New York: Routledge.

Van Mulken, M. (2003). Analyzing rhetorical devices in print advertisements. Document design, 4(2), 114-128. 